\title{
Applying Ayittey's Indigenous African Institutions to generate epistemic plurality in the curriculum
}

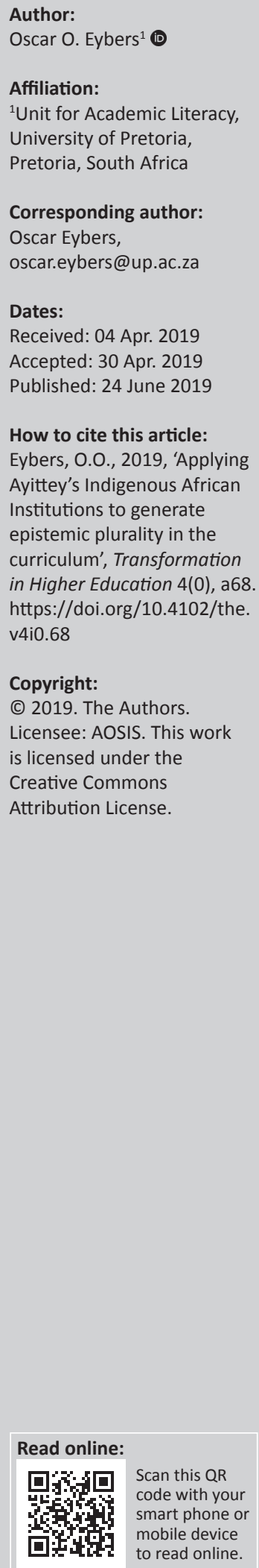

Background: South Africa's institutions of higher learning are currently experiencing a dispensation in which calls for curricula transformation and decolonisation reverberate. While the need for curricula evolution is generally accepted, there appears to be a lack of awareness of methodologies which are applicable to changing curricula. To this end the study proposed the incorporation of Ayittey's text Indigenous African Institutions into mainstream curricula for the following reasons: It is a rich source of indigenous African knowledge and includes history and information which relate to all disciplinary faculties and their areas of teaching.

Aim: The following conceptual study aimed to highlight the value of George Ayittey's seminal text, Indigenous African Institutions of 2006, towards implementing curricula in South African universities that are epistemically diverse.

Setting: This study is contextualised in higher learning spaces in the African context.

Method: The methods of this study involved a textual probing of previous discourses on epistemic diversity in university curricula that value pre-colonial African history. The study also highlighted pre-colonial African modes of organisation as emphasised in Ayittey's texts, which are relevant epistemic sources for dissemination in contemporary, African scholarly.

Results: The results of the study indicated that Africa's pre-colonial era contains rich sources of indigenous and epistemic knowledge required for social organisation during that era. Ayittey's text describes how African cultures gave form to relationships between families, communities, nations and the natural environment. This knowledge was seen as valuable for curriculum developers who aim to implement epistemically diverse curricula in mainstream African university modules.

Conclusion: The study concluded by conceptually arguing for curricula that incorporate and draw on regional and global contexts. Ayittey's text is an enabling instrument in such a curricula model that aims to increase student awareness of indigenous African epistemic systems and modes of organisation, as related to the rest of the humanity. It was also argued that when juxtaposed with western epistemic modes in the curriculum, Africa's epistemologies may aid in creating inclusive learning experiences.

Keywords: George Ayittey; indigenous knowledge; epistemic pluralism; curricula; diversity.

\section{Introduction}

South Africa has recently experienced turmoil in its tertiary sphere. While much of it derived from students' financial grievances, an equal amount of discontent emerged because of ideological disgruntlement (Angu 2018; Nyamnjoh 2016; Pillay 2016). Increasingly, segments of the student populace rebelled against what they experienced as colonised or Eurocentric paradigms in South African universities. A statue of Cecil Rhodes, based at the University of Cape Town, came to be seen as a symbol of black oppression and pain. This sentiment reflects Mbembe's (2015:2) suggestion that 'Cecil Rhodes belonged to [a] race of men who were convinced that to be black was a liability'. The current study is concerned with conceptualising curricula that reverse students' experiences of alienation or pain by replacing these with belonging. Carolissen and Kiguwa (2018:1-2) acknowledge that experiences of belonging may be shaped by power relations in universities. Such power relations, in turn, emerge from numerous variables that are not 'unidimensional' in nature but entail 'complex intersectionalities' (Carolissen \& Kiguwa 2018:3). In these configurations, variables such as race, gender, culture or ideological orientation are efficacious. But as Carolissen and Kiguwa (2018:3) acknowledge, in South Africa, 'black students [...] despite [their] legitimate student status [...] continue to experience their rights 
within universities as conditional, contingent, marginal and, circumscribed by the terms of the other'. Such experiences emerge, partially, because of institutional cultures that render fragile students' sense of belonging. Cabrera et al. (1999:135) argue that when students are exposed to an environment that includes discrimination or prejudice, they are prone to withdraw from it. Because of these real experiences and observations, this study aims to examine the role that precolonial African history and culture may contribute towards epistemic pluralisation of disciplinary fields in South African universities. It will argue that Ayittey's Indigenous African Institutions (2006), by virtue of its title and scope, is a rich source of knowledge that is capable of infusing continental knowledge into tertiary level curricula. The infusion of pre-colonial epistemologies - including cultural and organisational systems - into the system is then argued as a textual mechanism to reduce student alienation.

\section{Literature review}

\section{Indigenous African Institutions and epistemic diversity}

It is impossible to implement epistemically diverse curricula in South Africa without knowledge of how Africans lived in the pre-colonial dispensation. Asante (1991:28) argues that curricula should 'place [students] or centre [emphasis added] them, within the context of familiar cultural and social references from their own historical settings'. Failure to implement pedagogies that ground students in their cultures and identities risks 'destroying their sense of place' (Asante 1991:30). In South African universities, alienation among many students is a reality (Smit 2012:373). It is therefore essential to draw on the richness that pre-colonial African history and epistemic modes offer towards the project of developing inclusive learning experiences for all students of higher learning in South Africa.

Assie-Lumumba (2012) declares that in pre-colonial Africa, the purpose of education was to prepare young people to be responsible members of the community. She further stresses that during this dispensation, education was provided and equally received by all members of communities (AssieLumumba 2012:24). While elders were responsible for sharing principles and values required for adulthood and the survival of the community, the receptors of this knowledge passed it on to the youngest of children (Assie-Lumumba 2012:24). Instruction from elders included knowledge related to community legends, traditions, including ways of interacting with the natural environment, and local history (AssieLumumba 2012:24). Like educational systems worldwide, pre-colonial African modes of instruction also aimed to teach 'the various [...] technologies, sciences, art, music and traditional laws of governance. In all these it [had] its own philosophy, content and method of teaching' (Fordjor et al. 2003:185). Within this vein, if curricula in South African universities are to be epistemically diversified, there must be an alternative pedagogical model that acknowledges epistemic ways Africans employed to educate their communities and interact with the natural environment in the pre-colonial era. Ayittey's text provides ample examples of epistemic practices and principles that could be incorporated into contemporary curricula towards achieving this purpose.

\section{Curricula implications of philosophies and principles underpinning indigenous African institutions}

For South African universities of higher learning to epistemically diversify curricula in mainstream disciplines and fields of studies, it is necessary to recall, reflect upon and incorporate principles and values that generated indigenous African institutions. This process involves what has come to be termed a process of decoloniality. Saurombe (2018) conceives of the decolonial process as reintroducing the humanness of African agency, their cultures and histories, into the curriculum. Such a process is essential because a colonially inherited education system has 'excluded indigenous epistemologies and practices of [...] South African people' (Saurombe 2018:122). Fomunyam and Teferra (2017) agree with this claim. In their view, decoloniality involves 'the foregrounding of local or indigenous knowledge and experiences in curricula content, thereby downplaying [...] Eurocentric or global north experiences which [have] dominated curriculum content for centuries' (Fomunyam \& Teferra 2017:197).

Decolonisation, in the above context, involves an increase of curricula focus on indigenous knowledge and experiences to reduce perceived hegemony of Eurocentrism. Himonga and Diallo (2017:5) declare that decoloniality entails a move to more inclusive educational cultures. For these reasons, Ayittey's text, Indigenous African Institutions (2006), is critical for the African project of decolonising and implementing epistemically diverse curricula in our universities. It highlights how, in every domain of human social organisation, African knowledge systems and ways of doing may be incorporated into mainstream disciplinary curricula.

\section{Embedding African epistemologies in the university curriculum}

Most South African universities have faculties related to Humanities, Law, Science and Commerce. Ayittey's (2006) text illustrates how Africans organised and structured their societies in each of these domains. As argued by the scholars above, knowledge of indigenous African practices is essential to implement more Africanised and epistemically inclusive curricula.

\section{Humanities}

The humanities constitute a broad field of study. They include, but are not limited to, disciplines as diverse as fine art, linguistics, sociology, psychology, anthropology, political science and education. Fields of studies associated with humanities are also referred to as social sciences. According to the Economic and Social Research Council of the United Kingdom (2018:1), 'social science is [...] in its broadest sense, the study of society and the manner in which people 
behave and influence the world around us'. Drawing on this definition, an epistemically diverse curriculum that values local knowledge and contexts should, in addition to illustrating western modes of organisation, highlight African ways of engaging in human relations and the natural environment during the pre-colonial dispensation. Starting with artistic expression, it is well known that southern Africa has evidence of the most ancient examples of rock painting (Henshilwood, D'errico \& Watts 2009). Incorporating knowledge of the history and theoretical approaches towards these works enables lecturers and students alike to embed their experiences in an African framework. Ancient African art may be incorporated into the curriculum of literacy, linguistic and language courses. In Ayittey's (2006) text, art - whether verbal, musical or in image - is presented as having fulfilled a critical function in transmitting cultural values of communities. Ayittey (2006:36) writes that 'African art, dance, music and, other human activities were [...] intertwined with every aspect of life'. However, and from an ontological perspective, indigenous African art, in its multitude of manifestations, reveals how in the pre-colonial era 'the metaphysical sphere, was not divorced from concrete experience, especially since the physical and the metaphysical were aspects of reality' (Ayittey 2006:36). The value of these epistemic and ontological approaches, as emerging from indigenous African institutions, is that if they are applied in the lecture hall or classroom, students, too, may apply them as alternative modes of generating knowledge, as did Africans during the precolonial dispensation. By incorporating the values and principles underpinning artwork in the pre-colonial phase, lecturers and students may, in unique ways, experience an epistemically diverse curriculum that simultaneously draws on their own, local ways of knowing.

\section{Law}

Ayittey's Indigenous African Institutions (2006) suggests that Africa has among the most ancient of legal systems in the world. Bohannan (1968) concurs by stating that Africa is home to some of humanity's oldest legal systems. These were necessary because in Africa, as elsewhere, societies 'cannot exist without rules and principles that govern relationships between a person and other persons, the community and the environment' (Ayittey 2006:67). Of the numerous examples that Ayittey $(2006: 71,74,75)$ offers of indigenous legal systems in Africa, he mentions family-orientated legal modes of the Ga-dangme people who populate regions in Ghana, Togo and Benin. The dispute resolution systems of the Kpelle in Liberia and the Igbo of Nigeria are also highlighted, as is the elder-centred system of the Bukusu people of Kenya. As with global, legislative processes, precolonial legal systems in Africa were buttressed by sets of principles. Variations in African legal principles emerged because of their geographic origins and according to the structure of societies. For example, in the Ga-dangme, family-orientated system, the weku yitso, or family head, is responsible for embodying 'virtues and values that the family seeks to portray [and] to ensure proper [...] conformity of the actions of members of the family to group-approved standards' (Ayittey 2006:71). A critical function of the weku yitso was to preserve harmony among community and family members. Legal principles that the weku yitso valued and would apply are avoidance of shia-sane [conflict], okadi [evidence] and odasefoi [the involvement of witnesses] (Ayittey 2006:71). The agency afforded to the weku yitsos, and their responsibility for maintaining order among families, was similar to judges who preside over disputes. The significance of these examples of indigenous African legal systems is that they are still relevant to not only contemporary law classes but may be embedded in curricula across faculties to reveal how - philosophically, culturally and through language - Africa's pre-colonial era represents a rich source of knowledge that may aid in epistemically diversifying contemporary curricula in South African universities.

\section{Natural sciences}

As with its traditional legal practices, pre-colonial Africa equally evidences ample examples of how the people of the continent interacted with the natural environment. In the contemporary age, such interactions and the study thereof are associated with the natural sciences. Examples of scientific practices that emerge from Africa's Iron Age include:

Discoveries of several [...] furnaces and smelted iron artefacts in Cameroon, Gabon, Central African Republic and Congo, dating from $[3,000$ and 2,000 years ago] indicat $[i n g]$ that $[\ldots]$ Bantu farmers [possessed] the technology for iron metallurgy. (Bayon et al. 2012)

The introduction of iron technologies among African societies significantly altered agricultural methods, as stronger and more sophisticated tools were developed (Van Der Merwe \& Avery 1982). The impact of new farming tools and techniques contributed to the shift of many communities from huntergather or pastoralist societies to settled formations who engaged in crop farming (Oliver, Oliver \& Fagan 1975). Examples of these crops include pearl millet and yams (Oliver et al. 1975). Noticeably, these communities also began to increase their domestication of cattle, to maintain surpluses of foods and to cultivate wealth through the possession of these commodities (Ayittey 2006:401). It is impossible to exhaust analysis of Africa's Iron Age and the technological effects it had on a significant proportion of African people. Consideration and recalling of Africa's Iron Age is but one facet of how the natural sciences were applied in the precolonial era. African architecture, utilisation of natural medicines and modes of water-based travel all reveal how Africans were innovators in their own right. Such knowledge, whether in natural sciences or other faculties, has the potential to challenge stereotypes of pre-colonial Africa as a 'dark continent' and epistemically diversify curricula.

\section{Commerce}

Contrary to the colonial narrative that Africans lived wildly or even haphazardly, Africans possessed age-old systems of 
manipulating the natural environment to produce various goods for subsistence and trade (Ayittey 2006; Conrad 1996). Schneider (1986:181) states that 'while Africans often conducted their economic affairs in ways not identical to [the West], their behaviour can still be considered economic and commensurate with a market process'. A market process, of which Ayittey's text (2006:317-319) provides ample examples, involves the ways and means by which people organise production, exchange and distribute goods, as well as acquire finance under the authority of traditional authorities. With a lens on western Africa, Skinner (1964:205) observes that the region:

[h] ad economies which made agricultural produce available in amounts large enough to be sold in rural and urban markets [as well as] crafts specialisation often organised along the line of craft guilds [...] whose members manufactured goods to be sold at these markets.

Pre-colonial Africans partook in commercial practices that extended beyond regional domains. Skinner (1964:355) describes how 'markets served as local exchange points or nodes, and trade was the vascular system unifying all of West Africa, moving products to and from local markets, larger market centres, and still larger centres'. The significance of Africa's pre-colonial commercial systems for contemporary development of epistemically plural curricula is that they will enable students, not just of commerce-related subjects, but all disciplines, to perceive how Africa's socio-economic organisation was dynamic and evolving.

\section{The essence of Indigenous African Institutions}

The significance of Ayittey's text is that it highlights to readers the depth and richness that African pre-colonial epistemologies and modes of organisation represent. Indeed, when reflecting on Africa's immense socio-economic crisis, Ayittey (2006:11) argues that some of the core causes for such conditions relate to 'difficulty $[i n]$ penetrating [...] layers of mythology [and] ignorance [...] enshrouding Africa and [her] people'. This sentiment correlates with the principles of scholars in the decolonial domain who argue that Africa's cultures, epistemologies and traditions are marginalised in contemporary curricula (Angu 2018; Kumalo 2018; Nyoka 2013). Angu (2018) describes the constraints of African epistemologies in tertiary curricula as a process of marginalisation. Kumalo (2018), applying the concept of abjection, the non-seeing of blackness or African culture, argues that decoloniality must address this concern. Likewise, in theorising decoloniality, Nyoka (2013) points out the effects of negation of the African experience in tertiary experiences. Here, those ways that are authentically African, or have originated in the African lived and historical experience, are negated by curricula theorists, designers and implementers. Ayittey's text may, therefore, be approached as a source that is applicable as data or evidence of Africa's epistemic richness. In revealing to the reader how in every human sphere, be it agriculture, modes of social organisation, literacy practices, law, economic practices and art, Africa may be scrutinised as a source of knowledge and not a dark continent which has little to contribute to how we approach knowledge in the higher education arena. Nyoka (2013) argues that it is problematic to solely view disciplinary content via western theoretical lenses and frameworks. If we adopt this stance, then Indigenous African Institutions as a repository of African epistemic modes and ways of doing, may be applied towards designing epistemically plural curricula.

\section{Conceptual argument}

Ayittey's text, in the outlook of this study, is an effective tool for two reasons. Firstly, it may aid in the process of Africanising tertiary-based curricula; secondly, it may contribute towards diversifying active epistemologies in the lecture hall. The first objective was discussed above. By sharing insight into pre-colonial modes of organisation and associated cultural principles, Ayittey provides ample data and information to steer curricula towards a more African-centred orientation. However, the stance of the current study is that because of Africa's, South Africa's and the globe's multicultural character, effective application and incorporation of Ayittey's text in curricula designs should co-exist with western and other epistemologies. African epistemic modes should not be presented exclusively. As Teffo (2011:25) argues, 'the East, West and Africa have each played historic roles in generating and disseminating knowledge, science and culture'. Africa does not exist in isolation. While unequal in many respects, it is undeniable that because of the evolution of technology and other variables such as globalisation, the world is becoming a smaller place (Asongu \& Nwachukwu 2017). As such it is necessary for African universities to develop among the student populace those epistemologies and associated practices that are required not only in Africa, but throughout the globe. Such pedagogy is referred to as global citizenship education (Goren \& Yemeni 2017). Disciplinary modules are suitable structures for embedding African and global epistemologies. This intersection is illustrated in Figure 1.

\section{Discussion and conclusion}

Eurocentric curricula and methodologies in southern African universities are unable to generate learning experiences that are multicultural in character and are epistemically just. Instead, they reproduce inequalities in higher learning spaces that are manifest in greater society. Such epistemic injustice 'grant[s] differential levels of credibility and intelligibility to individuals based on their membership in different social groups' (Catala 2015:424). Continuing in such an epistemic trajectory is untenable for South Africa. Rather, regional institutions of higher learning require curricula that value epistemic plurality (Solomon 2006). In such pedagogic environments, the histories, epistemic traditions and ways of doing of multiple communities are incorporated into the curriculum. Ayittey's Indigenous African Institutions (2006) is applicable in fostering development of 


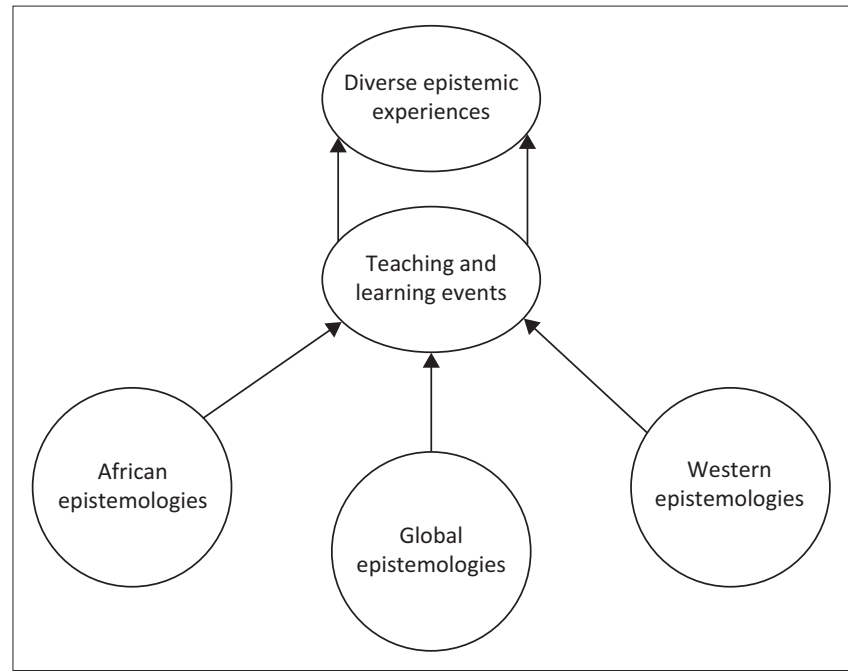

FIGURE 1: Interplay of African, global and western epistemologies in the curriculum.

epistemically diverse curricula by contributing the African side of things. His text, while only one perspective of precolonial Africa, re-introduces those principles and practices of social and knowledge organisation that were lost in the implementation of contemporary disciplines. While epistemically juxtaposing pre-colonial modes with global knowledge processes, students' experiences of alienation may be reduced, and universities may reap the benefits of curricular cultural richness.

Curricula that draw on the knowledge and history highlighted in Ayittey's text should not be presented in an exclusive manner. That is, African epistemologies and pre-colonial modes of organisation should be taught alongside alternative philosophies and theories that enhance understanding of disciplinary content. By drawing on the richness that diverse human cultures have to offer in the curriculum, we may enable students' development into experts who are aware of their African foundations and, simultaneously, of their status as citizens of the global community. West-Pavlov (2017) conceptualises the structures of such interaction as 'participatory cultures'. It is undeniable, however, that the history of higher education in Africa has experienced Eurocentrism. As such it is necessary to re-centre African epistemologies in the classroom. By juxtaposing these epistemic strategies with those ways of knowing as emerging from around the globe, we prepare, in the outlook of this study, our students to operate in a world that is culturally and organisationally diverse.

\section{Acknowledgements}

The author thanks Dr Pineteh Angu for his critical feedback.

\section{Competing interests}

The author declares that he has no financial or personal relationships that may have inappropriately influenced him in writing this article.

\section{Authors' contributions}

I declare that I am the sole author of this research article.

\section{Ethical considerations}

No human participants were empirically engaged in this study therefore ethical clearance was not required by the author's institution.

\section{Funding}

This research received no specific grant from any funding agency in the public, commercial, or not-for-profit sectors.

\section{Data availability statement}

Data sharing is not applicable to this article as no new data were created or analysed in this study.

\section{Disclaimer}

The views and opinions expressed in this article are those of the authors and do not necessarily reflect the official policy or position of any affiliated agency of the authors.

\section{References}

Angu, P., 2018, 'Disrupting Western epistemic hegemony in South African universities: Curriculum decolonisation, social justice, and agency in Post-Apartheid South Africa,' The International Journal of Learner Diversity and Identities 25(1), 9-22. https://doi.org/10.18848/2327-0128/CGP/v25i01/9-22

Asante, M.K., 1991, 'The Afrocentric idea in education', The Journal of Negro Education 60(2), 170-180. https://doi.org/10.2307/2295608

Asongu, S.A. and Nwachukwu, J.C., 2017. The comparative inclusive human development of globalisation in Africa. Social Indicators Research, 134(3), 1027-1050.

Assie-Lumumba, N., 2012, 'Cultural foundations of the idea and practice of the teaching profession in Africa: Indigenous roots, colonial intrusion, and postcolonial reality', Educational Philosophy \& Theory 44(S2), 21-36. https://doi.org/ 10.1111/j.1469-5812.2011.00793.x

Ayittey, G.B.N., 2006, Indigenous African Institutions, 2nd edn., Transnational Publishers, Ardsley.

Bayon, G., Dennielou, B., Etoubleau, J., Ponzevera, E., Toucanne, S. \& Bermell, S. 2012, 'Intensifying weathering and land use in Iron Age Central Africa', Science 335(6073), 1219-1222. https://doi.org/10.1126/science.1215400

Bohannan, P., 1968, Justice and judgement amongst the Tiv, Oxford University Press, London.

Cabrera, A.F., Nora, A., Terenzini, P.T., Pascarella, E. \& Hagedorn, L.S., 1999, 'Campus racial climate and the adjustment of students to college: A comparison between white students and African-American students', The Journal of Higher Education 70(2), 134-134. https://doi.org/10.2307/2649125

Carolissen, R. \& Kiguwa, P. 2018, 'Narrative explorations of the micro-politics of students' citizenship, belonging and alienation at South African universities,' South African Journal of Higher Education 32(3), 1-11.

Catala, A., 2015, 'Democracy, trust, and epistemic justice', The Monist 98(4), 424-440. https://doi.org/10.20853/32-3-2542

Conrad, J., 1996, Heart of darkness, pp. 17-95, Springer, New York.

Education and Social Research Council, 2018, 'What is social science?', viewed 3 January 2019, from https://esrc.ukri.org/about-us/what-is-social-science/.

Fomunyam, K.G. \& Teferra, D., 2017, 'Curriculum responsiveness within the context of decolonisation in South African higher education', Perspectives in Education 35(2), 196-207. https://doi.org/10.18820/2519593X/pie.v35i2.15

Fordjor, P., Kotoh, A., Kuma Kpeli, K., Kwamefio, A., Bernard, M., Owusu, E. et al., 2003, 'A review of traditional Ghanaian and Western philosophies of adult education', International Journal of Lifelong Education 22(2), 182-199. https://doi.org/ 10.1080/0260137032000055321

Goren, H. and Yemini, M., 2017. Global citizenship education redefined-A systematic review of empirical studies on global citizenship education. International Journal of Educational Research, 82, 170-183. https://doi.org/10.1016/j.linged. 2018.11.001

Henshilwood, C.S., D'errico, F. \& Watts, I., 2009, 'Engraved ochres from the middle stone age levels at Blombos Cave, South Africa, Journal of Human Evolution 57(1), 27-47. https://doi.org/10.1016/j.jhevol.2009.01.005 
Himonga, C. \& Diallo, F., 2017, 'Decolonisation and teaching law in Africa with special reference to living customary law', Potchefstroom Electronic Law Journal/ Potchefstroomse Elektroniese Regsblad 20(1), 1-19. https://doi.org/10.17159/ 1727-3781/2017/v20i0a3267

Kumalo, S.H., 2018, 'Explicating abjection - Historically white universities creating natives of nowhere?', Critical Studies in Teaching and Learning', 6(1), 1-17. https://doi.org/10.14426/cristal.v6i1.132

Mbembe, A, 2015, 'Decolonizing knowledge and the question of the archive', Unpublished manuscript, viewed from n.d., http://wiser.wits.ac.za/system/files/ Achille $\% 20$ Mbembe $\% 20-\% 20$ Decolonizing $\% 20$ Knowledge $\%$.

Nyamnjoh, F.B., 2016, Rhodes must fall: Nibbling at resilient colonialism in South Africa, Langaa Research and Publishing, Bamenda, Cameroon.

Nyoka, B., 2013, 'Negation and affirmation: A critique of sociology in South Africa', African Sociological Review/Revue Africaine de Sociologie 17(1), 2-24.

Oliver, R.A., Oliver, R. \& Fagan, B.M., 1975, Africa in the Iron Age: c. 500 BC-1400 AD, Cambridge University Press, Cambridge.

Pillay, S.R., 2016, 'Silence is violence: (critical) Psychology in an era of Rhodes Must Fall and Fees Must Fall', South African Journal of Psychology 46(2), 155-159. https://doi.org/10.1177/0081246316636766
Saurombe, N., 2018, 'Decolonising higher education curricula in South Africa: Factoring in archives through public programming initiatives', Archival Science: International Journal on Recorded Information 18(2), 119-141.

Schneider, H.K., 1986, 'Traditional African economies', in P.M. Martin \& P. O'Meara (eds.), pp. 181-198, Indiana University Press, Bloomington, IN.

Skinner, E.P., 1964, 'West African economic systems', in M.J. Herskovits \& M. Harwitz (eds.), Economic transition in Africa, pp. 77-97, Northwestern University Publishers, Evanston, IL.

Smit, R., 2012, 'Towards a clearer understanding of student disadvantage in higher education: Problematising deficit thinking', Higher Education Research \& Development 31(3), 369-380. https://doi.org/10.1080/07294360.2011.634383

Solomon, M., 2006, 'Norms of epistemic diversity', Episteme 3(1-2), 23-36.

Teffo, L., 2011. Epistemic pluralism for knowledge transformation. International Journa of African Renaissance Studies-Multi-, Inter-and Transdisciplinarity, 6(1), 24-34.

Van Der Merwe, N.J. \& Avery, D.H., 1982, 'Pathways to steel: Three different methods of making steel from iron were developed by ancient peoples of the Mediterranean, China, and Africa', American Scientist 70(2), 146-155.

West-Pavlov, R., 2017, 'Participatory cultures and biopolitics in the global South in In Koli Jean Bofane's Congo Inc', Research in African Literatures 48(4), 105-121. https://doi.org/10.2979/reseafrilite.48.4.08 